\title{
THROMBOPLASTIN GENERATION ACCELERATOR, A NEWLY RECOGNIZED COMPONENT OF THE BLOOD COAGULA- TION MECHANISM PRESENT IN EXCESS IN CERTAIN THROMBOTIC STATES *
}

\author{
By CHRIS A. PASCUZZI, JOHN A. SPITTEL, JR., JOHN H. THOMPSON, Jr. AND \\ CHARLES A. OWEN, JR. WITH THE TECHNICAL ASSISTANCE OF \\ CHARLENE MATTHEES \\ (From the Sections of Medicine and Clinical Pathology, Mayo Clinic and Mayo \\ Foundation, Rochester, Minn.)
}

(Submitted for publication October 31, 1960 ; accepted March 2, 1961)

Recent years have witnessed an increasing interest in the study of the possible relationship of blood coagulation to intravascular thrombosis (1-4). In spite of numerous methods of investigation, a consistent means of demonstrating and defining a clotting abnormality in thromboembolic diseases has not emerged.

By retarding artificially the thromboplastin generation test (TGT) we have been able to show acceleration of thromboplastin generation in certain patients with intravascular thrombosis $(5,6)$. Our experience to date indicates that 75 per cent of 52 patients who had arteriosclerosis obliterans with thrombosis demonstrated the acceleration, 50 per cent of 40 patients with "idiopathic" recurrent thrombophlebitis did likewise, but only 11 per cent of 35 patients who had arteriosclerosis obliterans without thrombosis exhibited acceleration of the TGT. Of several hundred "normal" plasmas, less than 1 per cent was abnormally rapid in the TGT. It became apparent that the cause of the rapid formation of thromboplastin in the blood of these patients was demonstrable only in the adsorbed plasma reagent of the TGT, not in the serum reagent. Since the adsorption of plasma removes plasma thromboplastin component (PTC or factor IX), stable factor (factor VII), and Stuart factor (factor $\mathrm{X}$ ), as well as prothrombin, these substances are probably not directly involved in the clot acceleration. A number of other factors remains; these are considered in detail in the present report.

We wish to present evidence that the abnormal clot acceleration results from the presence of an

* This investigation was supported in part by research grant H-5008(R1) from the National Institutes of Health. excessive amount of coagulative activity which resides with the globulins in normal human plasma. We have designated this protein "thromboplastin generation accelerator," or simply "TGA," because its activity seems to lie in the thromboplastin generation phase of clotting.

\section{METHODS}

1. One-stage prothrombin time of Quick (7). This test, as modified locally (8), gives a normal value of 17 to 19 seconds. For the determinations of "dilute prothrombin time," fresh plasma was diluted 1:5 and 1:10 with oxalated saline solution ( 1 part of $0.1 \mathrm{M}$ sodium oxalate and 9 parts of 0.9 per cent sodium chloride), and the test was carried out in the usual manner. Normal values are 30 to 49 seconds for the $1: 5$ dilution of plasma, and 56 to 67 seconds for the 1:10 dilution.

2. Plasma clotting (recalcification) time (9). The normal value is 90 to 110 seconds.

3. Thromboplastin generation test (TGT) of Biggs and Douglas (10), modified by Duckert and co-workers (11), with substitution of soybean phosphatides for platelets (12). Normal values are the shortest clotting times, 8 to 11 seconds, occurring at 7 to 11 minutes of incubation. Retardation of the TGT (6) is carried out by diluting the plasmatic reagent $1: 50$ with buffered saline [ 1 part of imidazole buffer (13) and 9 parts of 0.9 per cent sodium chloride] instead of our usual $1: 25$ dilution [Duckert modification (11)]. Normal values for the "retarded TGT" are the shortest clotting times, 13 to 16 seconds, occurring at 11 to 13 minutes of incubation. Since we have demonstrated excess TGA activity as well with soybean phosphatide as with platelets (5), the convenience of the former has led to its routine use.

4. Electrophoresis of plasmatic factors (14). The fresh plasma was first treated with barium sulfate $(50 \mathrm{mg}$ per $\mathrm{ml}$, for 5 minutes at $24^{\circ} \mathrm{C}$ ) to remove prothrombin and factors VII, IX and X; $0.15 \mathrm{ml}$ was applied to strips of Whatman no. 2 filter paper, $4 \mathrm{~cm}$ wide. Electrophoresis was carried out in a cold room $\left(4^{\circ} \mathrm{C}\right)$ for a period of 16 hours at a constant current of $0.6 \mathrm{ma}$ per $\mathrm{cm}$ width of paper strips; the buffer used was sodium barbital-bar- 
bituric acid of $\mathrm{pH} 8.6$ and 0.05 ionic strength. The various cut-paper fractions were eluted with $2.5 \mathrm{ml}$ of buffered saline.

5. Precipitating with ammonium sulfate. At room temperature, $1 \mathrm{ml}$ of fresh barium sulfate-adsorbed plasma, diluted to a total volume of $10 \mathrm{ml}$, was subjected to progressively greater concentrations of saturated solution of ammonium sulfate after removal by centrifugation of the precipitate formed in each preceding step. The various precipitates were dissolved and subjected to dialysis against several changes of 0.9 per cent sodium chloride for 16 hours at $4^{\circ} \mathrm{C}$.

\section{MATERIALS}

1. Excess TGA plasma. This was obtained from patients with arteriosclerosis obliterans and associated thrombosis. All of these samples of plasma exhibited increased thromboplastic activity in the thromboplastin generation tests whether the plasma was diluted $1: 25$ or $1: 50$. This increase in activity ranged from approximately two to five times the normal rate of generation of thromboplastin. These values were estimated by comparison with the thromboplastin-generating activity of normal plasma. Essentially, the thromboplastin generated at various intermediate intervals of time is calculated from serial dilutions of the control and patient plasmas. If, for example, at the fifth minute of incubation twice as much thromboplastin has been generated by the patient as by the control, the activity is recorded as two times normal.

On the other hand, in the studies of the properties of TGA (electrophoretic mobility, precipitation, and heat stability) an attempt at more direct evaluation of TGA activity was made by the degree of augmentation of the generation of thromboplastin by normal plasma to which the fraction was added.

2. AHG-deficient plasma. Fresh plasma was obtained repeatedly from 2 severely hemophilic patients. These samples were cross checked with samples from 6 other hemophilic patients and all 8 exhibited the same defect, a lack of the antihemophilic globulin (AHG or factor VIII).

3. Aged normal plasma. Fresh normal plasma was heated to $37.5^{\circ} \mathrm{C}$ for 24 to 30 hours until the prothrombin time exceeded 60 seconds and the plasma clotting time exceeded 300 seconds. This plasma has been shown to be deficient in both factor $\mathrm{V}$ and $\mathrm{AHG}$ when tested against plasmas of parahemophilic and hemophilic patients.

All samples of plasma were oxalated by the addition of $0.5 \mathrm{ml}$ of $0.1 \mathrm{M}$ sodium oxalate to $4.5 \mathrm{ml}$ of freshly drawn whole blood.

\section{RESULTS}

Certain known coagulation factors are present in normal aged serum (factors VII, IX, X, Hageman and PTA); others are active in fresh plasma that has been treated with one of the various chem- ical adsorbents, such as barium sulfate (factors V, VIII, Hageman, PTA and fibrinogen). The TGT is carried out by measuring the activity of plasma thromboplastin formed from a mixture containing serum, adsorbed plasma, platelets or platelet substitute, and calcium. Since thromboplastin generates only if all four reagents are present, replacement of the patient's serum or plasma with normal serum or plasma can lead to a preliminary delineation of the patient's abnormality.

We have shown in previous reports $(5,6)$ that acceleration of thromboplastin formation, when present, has always been restricted to the plasmatic reagent. Serum activity in the thromboplastin generation test in four representative cases in which accelerated thromboplastin formation was exhibited is shown in Table I. Serums in $\mathrm{Pa}$ tients 1, 2 and 3 were normal while the serum in Patient 4 was actually retarded because of the administration of coumarin drugs. The thromboplastin-generating activity of the plasmatic reagent in these patients ranged from two to five times normal. Because of this observation, it seemed unlikely that the serum factors could be responsible for the acceleration process.

Platelets likewise appear to bear no direct relationship to the phenomenon of plasma acceleration, since we have observed it in thrombocytopenic

TABLE I

\begin{tabular}{|c|c|c|c|c|c|}
\hline \multirow{2}{*}{$\begin{array}{l}\text { Incuba- } \\
\text { tion } \\
\text { time }\end{array}$} & \multirow{2}{*}{$\begin{array}{l}\text { Typical } \\
\text { control } \\
\text { serum }\end{array}$} & \multicolumn{4}{|c|}{ Coagulation time } \\
\hline & & Pt. 1 & Pt. 2 & Pt. 3 & Pt. 4 \\
\hline \multicolumn{2}{|l|}{$\min$} & \multicolumn{2}{|c|}{$\mathrm{sec}$} & \multicolumn{2}{|c|}{$\mathrm{sec}$} \\
\hline 1 & 65 & 90 & 93 & 78 & 52 \\
\hline 3 & 47 & 66 & 68 & 72 & 48 \\
\hline 5 & 45 & 42 & 47 & 41 & 45 \\
\hline 7 & 32 & 30 & & & 47 \\
\hline 8 & 21 & 16 & 26 & 15 & \\
\hline 9 & 12 & 14 & 15 & 12.5 & 39 \\
\hline 10 & 10 & 12 & 12 & 11 & 36 \\
\hline 11 & 9.5 & & 10 & 9 & \\
\hline 13 & 11 & 14 & 11.5 & 10.5 & 32 \\
\hline \multicolumn{2}{|c|}{$\begin{array}{l}\text { Plasma activ- } \\
\text { ity in TGT, } \\
\text { times normal }\end{array}$} & 2 & 2 & 4 & 5 \\
\hline
\end{tabular}

* Samples of serum $(1: 10)$ from 4 patients with thromboembolic disorders were combined with normal control plasma $(1: 25)$ in the TGT. Patient 4 was being treated with coumarin drugs; prothrombin time was 35 seconds at time of test. His serum yielded reduced thromboplastic activity; serum from the other three patients did not deviate significantly from normal. 
TABLE II

Stability of $T G A$ at $56^{\circ} C^{*}$

\begin{tabular}{|c|c|c|c|c|c|c|}
\hline \multirow{3}{*}{$\begin{array}{l}\text { Incuba- } \\
\text { tion } \\
\text { time }\end{array}$} & \multirow{2}{*}{$\begin{array}{l}\text { Normal } \\
\text { control } \\
\text { plasma }\end{array}$} & \multirow{2}{*}{$\begin{array}{c}\text { Excess } \\
\text { TGA } \\
\text { plasma } \\
\text { unheated }\end{array}$} & \multicolumn{4}{|c|}{$\begin{array}{c}\text { Excess TGA plasma heated } \\
\text { at } 56^{\circ} \mathrm{Ct}\end{array}$} \\
\hline & & & $5 \mathrm{~min}$ & $10 \mathrm{~min}$ & $15 \mathrm{~min}$ & $20 \mathrm{~min}$ \\
\hline & \multicolumn{6}{|c|}{ Clotting time } \\
\hline $\min$ & \multicolumn{2}{|c|}{$\sec$} & \multicolumn{2}{|c|}{$\sec$} & \multicolumn{2}{|c|}{$\sec$} \\
\hline $\begin{array}{r}1 \\
3 \\
5 \\
7 \\
8 \\
9 \\
10\end{array}$ & $\begin{array}{l}81 \\
66 \\
38 \\
26 \\
14 \\
13.5 \\
14\end{array}$ & $\begin{array}{l}56 \\
13 \\
10.5 \\
10.5 \\
10.5 \\
11.5\end{array}$ & $\begin{array}{l}48 \\
17 \\
11 \\
10.5 \\
11 \\
11.5 \\
12\end{array}$ & $\begin{array}{l}76 \\
32 \\
12 \\
11.5 \\
12 \\
13\end{array}$ & $\begin{array}{l}70 \\
25 \\
12 \\
11.5 \\
12 \\
12.5 \\
12.5\end{array}$ & $\begin{array}{r}108 \\
79 \\
42 \\
23 \\
16 \\
14 \\
15\end{array}$ \\
\hline
\end{tabular}

* Plasma containing excess of TGA was adsorbed with $\mathrm{BaSO}_{4}$ and diluted 1:50 in the TGT; normal serum was diluted 1:10. Increase in rate of generation and in amount of thromboplastin formed is evident.

† To maintain optimal AHG and factor V activity in heated samples, 1 vol fresh normal plasma $(1: 25)$ was mixed with 1 vol heated plasma $(1: 25)$; this mixture was then used as the plasmatic reagent in the TGT.

plasmas; and in our modification of the TGT, soybean phosphatide is used as a platelet substitute.

The series of experiments reported here were carried out for the purpose of determining which of the recognized factors present in adsorbed plasma and absent from serum, namely factors V, VIII and fibrinogen, might be responsible for the excessive thromboplastin formation in certain patients. Because we have not observed increased concentrations of fibrinogen in the plasma of these patients, our attack was directed primarily toward factors V and VIII. As will be shown subse- quently, fibrinogen appears to be excluded as the cause of increased formation of thromboplastin in these cases.

Heat-stability studies. We have found that excess TGA activity persists after warming the plasma to $37^{\circ} \mathrm{C}$ for 30 minutes and to $24^{\circ} \mathrm{C}$ for 24 hours, and after storage at $-20^{\circ} \mathrm{C}$ for as long as 1 year. A comparison of its lability at $56^{\circ} \mathrm{C}$ with factor $\mathrm{V}$ and $\mathrm{AHG}$ was carried out.

The stability of factor $\mathrm{V}$ (labile factor) was measured by determining the corrective effect of normal plasma ( $1 \mathrm{vol}$ ) on the prothrombin time of aged normal plasma (9 vol), after the normal plasma had been exposed to a temperature of $56^{\circ}$ $\mathrm{C}$ for various lengths of time. Normal plasma that had shortened the prothrombin time of the aged plasma from 85 to 30 seconds before heating exerted no effect on the long prothrombin time of the aged plasma after 1 minute at $56^{\circ} \mathrm{C}$. We found that after 15 seconds at $56^{\circ} \mathrm{C}, 30$ per cent of factor $\mathrm{V}$ activity remained; after 30 seconds, 12 per cent; after 45 seconds, 5 per cent; and after 60 seconds, 0 per cent. The thermolability of factor $\mathrm{V}$ in excess TGA plasma was indistinguishable from normal.

Stability of AHG was determined by heating fresh normal plasma to $56^{\circ} \mathrm{C}$ for various periods and then determining the effect of this plasma on AHG-deficient plasma by means of plasma recalcification times and thromboplastin generation tests. By these methods, AHG activity of nor-

TABLE III

Electrophoretic localization of $T G A^{*}$

\begin{tabular}{|c|c|c|c|c|c|c|c|c|c|c|c|}
\hline \multirow{3}{*}{$\begin{array}{c}\text { Incuba- } \\
\text { tion } \\
\text { time }\end{array}$} & \multirow[b]{2}{*}{$\begin{array}{l}\text { Control } \\
\text { system }\end{array}$} & \multicolumn{5}{|c|}{ Normal plasma fractions } & \multicolumn{5}{|c|}{ Excess TGA plasma fractions } \\
\hline & & $\begin{array}{c}\text { Albumin } \\
+\alpha_{1}\end{array}$ & $\alpha_{2}$ & $\boldsymbol{\beta}$ & $\gamma_{1}$ & $\gamma_{2}$ & Albumin & $\alpha_{1}$ & $\alpha 2$ & $\boldsymbol{\beta}$ & $\gamma_{1}+\gamma_{2} \dagger$ \\
\hline & \multicolumn{11}{|c|}{ Clotting time } \\
\hline $\min$ & $\sec$ & \multicolumn{2}{|c|}{$\mathrm{sec}$} & \multicolumn{2}{|c|}{$\mathrm{sec}$} & \multicolumn{2}{|c|}{$\mathrm{sec}$} & \multicolumn{2}{|c|}{$\mathrm{sec}$} & \multicolumn{2}{|c|}{$\mathrm{sec}$} \\
\hline 1 & 113 & 73 & 79 & 78 & 72 & 100 & 81 & 81 & 77 & 61 & 70 \\
\hline 3 & 79 & 72 & 73 & 65 & 50 & 72 & 78 & 86 & 68 & 52 & 52 \\
\hline 5 & 62 & 52 & 54 & 53 & 30 & 53 & 69 & 65 & 65 & 20 & 35 \\
\hline 7 & 41 & 36 & 38 & 22 & 14 & 42 & 49 & 35 & 30 & 10 & 13 \\
\hline 8 & 25 & 27 & 23 & 15 & 12 & 27 & 37 & 24 & 17 & 11 & 12 \\
\hline 9 & 18 & 15 & 16 & 14 & 12 & 19 & 21 & 16 & 14 & 11 & 11 \\
\hline 10 & 14 & 13.5 & 15 & 11 & 11.5 & 13 & 15 & 15 & 11 & 12 & 11 \\
\hline 11 & 13.5 & 13 & 14 & 11 & 13 & 13 & 15 & 15 & 10.5 & 12.5 & 12 \\
\hline 12 & 14 & 13.5 & 14 & 12 & & 14 & 13 & 15 & 11 & & 13 \\
\hline
\end{tabular}

* Barium sulfate-adsorbed normal plasma and excess TGA plasma (Patient 1, Table IV) were electrophoresed on paper strips (see Methods); zones were eluted with buffered saline and each was then used as diluent for normal plasmatic reagent in the TGT instead of the usual saline diluent. Accelerator activity was found in $\gamma_{1}$ and $\beta$ zones, the former related to activity of AHG and factor V, the latter to TGA (see text).

$\dagger$ The $\gamma_{1}$ and $\gamma_{2}$ zones were not clearly separable in this plasma and consequently were tested together. 
TABLE IV

Summary of electrophoretic analyses of TGA activity (in $\beta$-globulin) and AHG activity (in $\gamma$-globulin) in the plasmas of seven patients with excess TGA activity*

\begin{tabular}{|c|c|c|c|c|c|c|c|c|}
\hline \multirow[b]{3}{*}{ Pt. } & \multicolumn{4}{|c|}{$\beta$-globulin (TGA) activity } & \multicolumn{4}{|c|}{$\gamma_{1-\text { globulin }}(\mathrm{AHG})$ activity } \\
\hline & \multicolumn{2}{|c|}{ Normal control plasma } & \multicolumn{2}{|c|}{ Excess TGA plasma } & \multicolumn{2}{|c|}{ Normal control plasma } & \multicolumn{2}{|c|}{ Excess TGA plasma } \\
\hline & $\begin{array}{l}\text { Shortest } \\
\text { clotting at } \\
\text { time }\end{array}$ & $\begin{array}{c}\text { Incubation } \\
\text { time }\end{array}$ & $\begin{array}{l}\text { Shortest } \\
\text { clotting at } \\
\text { time }\end{array}$ & $\begin{array}{c}\text { Incubation } \\
\text { time }\end{array}$ & $\begin{array}{l}\text { Shortest } \\
\text { clotting at } \\
\text { time }\end{array}$ & $\underset{\text { Incubation }}{\text { Ine }}$ & $\begin{array}{l}\text { Shortest } \\
\text { clotting at } \\
\text { time }\end{array}$ & $\begin{array}{c}\text { Incubation } \\
\text { time }\end{array}$ \\
\hline & $\sec$ & $\min$ & $\sec$ & $\min$ & $\mathrm{sec}$ & $\min$ & $\sec$ & $\min$ \\
\hline $\begin{array}{l}1 \\
2 \\
3 \\
4 \\
5 \\
6 \\
7\end{array}$ & $\begin{array}{l}11 \\
12 \\
12.5 \\
12.5 \\
13.5 \\
14 \\
14.5\end{array}$ & $\begin{array}{r}10 \\
9 \\
8 \\
11 \\
8 \\
10 \\
16\end{array}$ & $\begin{array}{c}10 \\
12 \\
9.5 \\
11 \\
11 \\
12 \\
13\end{array}$ & $\begin{array}{r}7 \\
8 \\
8 \\
11 \\
7 \\
9 \\
13\end{array}$ & $\begin{array}{l}11.5 \\
12 \\
11.5 \\
11 \\
14 \\
13 \\
17\end{array}$ & $\begin{array}{r}10 \\
8 \\
8 \\
9 \\
8 \\
9 \\
16\end{array}$ & $\begin{array}{l}11 \\
12.5 \\
11 \\
10 \\
14 \\
14 \\
16.5\end{array}$ & $\begin{array}{r}9 \\
8 \\
8 \\
9 \\
8 \\
9 \\
16\end{array}$ \\
\hline
\end{tabular}

* The TGT was performed as described in Table III. Only the shortest clotting times and the time of incubation required to reach these times are listed. The AHG activity in all cases was comparable between the plasmas of patients and controls. In every instance there was more accelerating activity in the $\beta$-globulin of the excess TGA plasma than in the $\beta$-globulin of the control plasma subjected to electrophoresis concurrently.

mal plasma was found to be depressed about 70 per cent in 1 minute and about 90 per cent in 5 minutes, and was undetectable after 10 minutes of exposure to $56^{\circ} \mathrm{C}$. The thermolability of AHG in excess TGA plasma was indistinguishable. from normal.

The effect of heating excess TGA plasma to $56^{\circ}$ $\mathrm{C}$ is shown in Table II. It can be seen that the rate of thromboplastin generation was little affected for the first 15 minutes during which time both factor $\mathrm{V}$ and AHG activities had completely disappeared.

Electrophoretic identification. Fresh samples of seven different barium sulfate-adsorbed excess TGA plasmas, along with seven samples of normal control plasma similarly treated, were subjected to paper electrophoresis. Eluates of various zones on the paper strips were used as diluents for the normal plasmatic reagent in the TGT. Adsorbed plasma was used for electrophoresis in order to simplify the analyses by prior removal of factors VII, IX, $\mathrm{X}$ and prothrombin.

The complete TGT's of a typical case (Patient 1, Table IV) are listed in Table III. All seven cases are summarized in Table IV. Increased thromboplastin formation was obtained when eluates from $\beta$ and $\gamma_{1}$ fractions of either the normal control or excess TGA plasma were used as diluents. The $\gamma_{1}$ eluates of both the control and the excess TGA plasma showed approximately the same activity; however, the $\beta$ fraction of the excess TGA plasma exhibited a greater degree of thromboplastic activity than did the corresponding $\beta$ fraction from normal plasma. Comparable re- sults were obtained invariably in each of the other six studies (Table IV). It seems clear that TGA and AHG can be differentiated electrophoretically.

Eluates from the various fractions of both normal plasma and excess TGA plasma were tested for AHG activity (Table V). In every instance the eluate from the $\gamma_{1}$ region decreased the recalcification time of AHG-deficient plasma, while eluates from the other fractions failed to influence significantly the clotting time of the hemophilic plasma. The apparent difference between our finding and that of Lewis, Walters, Didisheim and Merchant (15) may be technical, since this group used continuous flow electrophoresis.

TABLE V

$A H G$ activity in electrophoretic fractions of normal plasma*

\begin{tabular}{ccc}
\hline \hline Plasma & $\begin{array}{c}\text { Clotting } \\
\text { time }\end{array}$ \\
\hline AHG-deficient plasma & sec \\
AHG-deficient plasma plus: & 440 \\
Albumin (fresh plasma) & 450 \\
$\beta$ & (fresh plasma) & 400 \\
$\gamma$ & (fresh plasma) & 300 \\
$\gamma_{1}$ & (aged plasma) & 410 \\
\end{tabular}

* Eluates of paper electrophoretic fractions were added to fresh AHG-deficient plasma in 1:10 ratio; plasma clotting times were determined on mixtures. Sample of aged plasma (free of AHG) was similarly treated as control. AHG activity seemed to concentrate in $\gamma_{1}$ zone. 


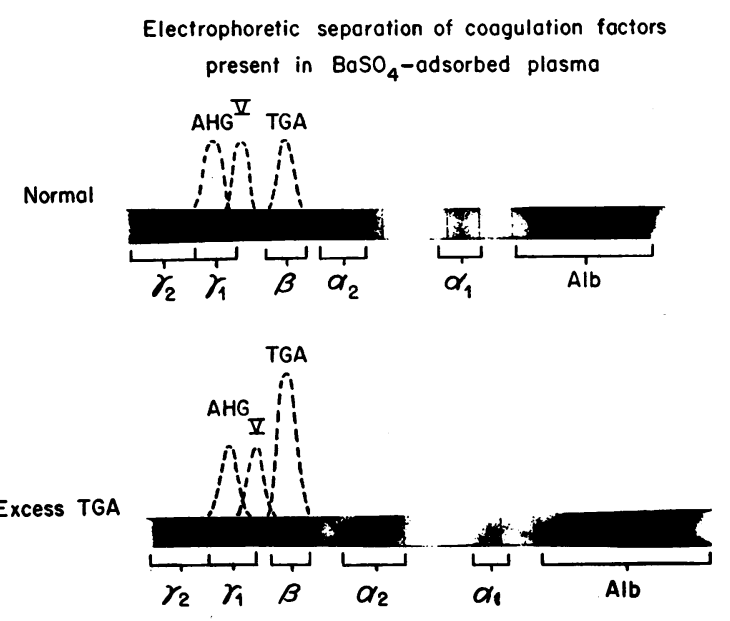

Fig. 1. Coagulation activities in the $\beta$ and $\gamma$ ZONES OF NORMAL PLASMA AND EXCESS TGA PLASMA,

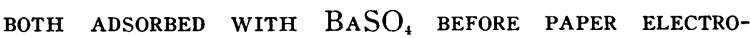
PHORESIS.

To exclude the effect of factor $\mathrm{V}$, which usually travels with the $\gamma_{1}$ plasma proteins (14), the eluates of the $\beta$ fraction of both the control plasma and the excess TGA plasma were heated to $56^{\circ} \mathrm{C}$ for 1 minute to inactivate completely any factor $\mathrm{V}$ that might have been present. These heated samples were then used as diluents for the plasmatic reagent in the TGT, as above. Neither the eluate from the control nor that from the excess TGA plasma showed any loss of activity after heating. It is assumed, therefore, that there was virtually no factor $\mathrm{V}$ activity in the $\beta$ fractions, and in turn that the $\beta$-globulin clotting activity was not attributable to factor $V$. In each electrophoretic test, fibrinogen was heavily concentrated at the point of application of the plasma to the paper strips in the $\gamma$ region, and far removed from the $\beta$ fraction.

Hageman factor activity has been shown to reside in the $\gamma_{1}$ fraction (16), and PTA activity in the $\beta-\gamma$ interspace (17); unlike TGA, however, both are present in serum.

Electrophoretic analyses of barium sulfate-adsorbed serum (lacking prothrombin and factors $\mathrm{V}, \mathrm{VII}, \mathrm{VIII}, \mathrm{IX}, \mathrm{X}$ and TGA, but containing PTA and Hageman factor) from normal controls and from patients with accelerated clotting were carried out and eluates from the various fractions were studied in a manner similar to that used for the plasma. No evidence of increased thromboplastic activity was found when these eluates were used as diluents in the TGT. It was assumed from this experiment that the presence of excessive amounts of Hageman factor and PTA in the TGT do not materially influence thromboplastin generation. The electrophoretic zones of activity of TGA, factor V, and AHG in normal and excess TGA plasma are illustrated in Figure 1.

Precipitating with ammonium sulfate. To corroborate the findings obtained by electrophoresis, precipitation experiments with ammonium sulfate

TABLE VI

Localization of TGA by precipitation with ammonium sulfate *

\begin{tabular}{|c|c|c|c|c|c|c|c|c|c|}
\hline \multirow{4}{*}{$\begin{array}{l}\text { Incuba- } \\
\text { tion time }\end{array}$} & \multirow{3}{*}{$\begin{array}{l}\text { Control } \\
\text { system† }\end{array}$} & \multicolumn{8}{|c|}{ Ammonium sulfate saturation } \\
\hline & & \multicolumn{4}{|c|}{ Fractions of normal plasma } & \multicolumn{4}{|c|}{ Excess TGA plasma fractions } \\
\hline & & $25 \%$ & $25-35 \%$ & $35-40 \%$ & $40-45 \%$ & $25 \%$ & $25-35 \%$ & $35-40 \%$ & $40-45 \%$ \\
\hline & \multicolumn{9}{|c|}{ Clotting time } \\
\hline $\min$ & $\sec$ & \multicolumn{2}{|c|}{$\sec$} & \multicolumn{2}{|c|}{ sec } & \multicolumn{2}{|c|}{$\sec$} & \multicolumn{2}{|c|}{$\sec$} \\
\hline $\begin{array}{r}1 \\
3 \\
5 \\
7 \\
8 \\
9 \\
10 \\
11 \\
12\end{array}$ & $\begin{array}{l}78 \\
74 \\
62 \\
35 \\
22 \\
14 \\
13 \\
13 \\
14\end{array}$ & $\begin{array}{l}69 \\
49 \\
19 \\
11 \\
11 \\
12 \\
12 \\
12 \\
13.5\end{array}$ & $\begin{array}{l}65 \\
49 \\
19 \\
14 \\
14 \\
13 \\
12 \\
12.5\end{array}$ & $\begin{array}{l}66 \\
41 \\
19 \\
12 \\
14 \\
11.5 \\
11.5 \\
13 \\
14\end{array}$ & $\begin{array}{l}79 \\
64 \\
40 \\
16 \\
13.5 \\
14.5 \\
13 \\
14 \\
14\end{array}$ & $\begin{array}{l}64 \\
55 \\
37 \\
17 \\
12.5 \\
12 \\
14\end{array}$ & $\begin{array}{l}76 \\
96 \\
70 \\
38 \\
17 \\
15 \\
12.5 \\
14 \\
14\end{array}$ & $\begin{array}{l}74 \\
53 \\
19 \\
11 \\
10 \\
8.5 \\
9.5 \\
13.5\end{array}$ & $\begin{array}{l}66 \\
66 \\
39 \\
\\
16 \\
13 \\
14 \\
14\end{array}$ \\
\hline
\end{tabular}

* Barium sulfate-adsorbed normal plasma and excess TGA plasma were fractionated with various concentrations of saturated ammonium sulfate. Precipitates were dissolved, freed of $\left(\mathrm{NH}_{4}\right)_{2} \mathrm{SO}_{4}$ by dialysis, and used as diluents $(1: 50)$ for plasmatic reagent (normal plasma) in the TGT. AHG activity is evident in $25 \%$ fractions, and TGA in 35 to $40 \%$ fractions, particularly in excess TGA plasma (see text). Reduced AHG activity of excess TGA plasma is probably related to 3-month storage of this plasma at $-20^{\circ} \mathrm{C}$.

t Buffered saline used as diluent. 
were performed. In these procedures, fresh normal plasma (control) and excess TGA plasma were initially adsorbed with barium sulfate and then subjected to fractionation with saturated ammonium sulfate. The precipitates from the various concentrations were dissolved, dialyzed and then used as diluents in the TGT. The influence of these fractions on the retarded TGT is shown in Table VI.

Both the 25 per cent and the 35 to 40 per cent ammonium sulfate saturation fractions of normal plasma and the excess TGA plasma exhibited increased thromboplastic activity. When tested against AHG-deficient plasma, the 25 per cent fractions were the most active in correcting the long clotting time of the hemophilic plasma; there was little difference between the 25 per cent fraction derived from normal plasma and that from excess TGA plasma (Table VII). On the other hand, the 35 to 40 per cent fraction from excess TGA plasma was significantly more active in accelerating normal thromboplastin generation in the TGT than was the same fraction from normal plasma. Neither 35 to 40 per cent fraction exhibited any AHG activity.

Dialysis studies. Fresh excess TGA plasma, barium sulfate-adsorbed excess TGA plasma and the 35 to 40 per cent ammonium sulfate saturation fraction of excess TGA plasma were dialyzed in cellophane bags against 0.9 per cent sodium chloride for 20 hours at $4^{\circ} \mathrm{C}$. No reduction of TGA activity was found in these plasmas; this is compatible with the concept that TGA is a protein.
TABLE VII

AHG activity in fractions obtained by precipitation from normal plasma with ammonium sulfate *

\begin{tabular}{lc}
\hline \hline & $\begin{array}{c}\text { Clotting } \\
\text { time }\end{array}$ \\
\hline & sec \\
AHG-deficient plasma & 209 \\
& \\
AHG-deficient plasma plus fraction & \\
obtained at saturation of: & \\
$25 \%$ & 157 \\
$25-35 \%$ & 190 \\
$35-40 \%$ & 204 \\
$40-45 \%$ & 211 \\
$45-50 \%$ & 196 \\
\end{tabular}

* Influence of ammonium sulfate-precipitated fractions of fresh normal plasma on prolonged recalcification time of AHG-deficient plasma is shown. Percentages refer to strength of saturated ammonium sulfate solution at which precipitation occurred. Precipitates were reconstituted after dialysis to equal plasma concentrations, then were added to AHG-deficient plasma in 1:9 ratio, and plasma clotting times determined on mixtures. The 25 per cent fractions presumably contained AHG (see text).

Effect of adsorbent chemicals. Each milliliter of plasma containing excess TGA was treated with barium sulfate $(50 \mathrm{mg})$ for 5 minutes at $24^{\circ} \mathrm{C}$, tricalcium phosphate $(0.1 \mathrm{ml}$ of a $0.2 \mathrm{M}$ suspension) for 5 minutes at $24^{\circ} \mathrm{C}$, or aluminum hydroxide $(0.1 \mathrm{ml}$ of a 6.1 per cent suspension $)$ at $0^{\circ} \mathrm{C}$ for varying periods of time and then tested in the TGT. Normal plasma similarly treated was used as the control. The results are shown in Table VIII. Accelerated generation of thromboplastin was equally apparent after the barium sulfate and tricalcium phosphate treatment. On

TABLE VIII

Action of adsorbing agents on TGA *

\begin{tabular}{|c|c|c|c|c|c|c|}
\hline \multirow{3}{*}{$\begin{array}{c}\text { Incubation } \\
\text { time }\end{array}$} & \multicolumn{2}{|c|}{$\mathrm{BaSO}_{4}$-adsorbed } & \multicolumn{2}{|c|}{$\mathrm{Ca}_{3}\left(\mathrm{PO}_{4}\right)_{2}$-adsorbed } & \multicolumn{2}{|c|}{$\mathrm{Al}(\mathrm{OH})_{3}$-adsorbed $\dagger$} \\
\hline & $\begin{array}{c}\text { Normal } \\
\text { plasma }\end{array}$ & $\begin{array}{c}\text { Excess TGA } \\
\text { plasma }\end{array}$ & $\begin{array}{c}\text { Normal } \\
\text { plasma }\end{array}$ & $\begin{array}{c}\text { Excess TGA } \\
\text { plasma }\end{array}$ & $\begin{array}{c}\text { Normal } \\
\text { plasma }\end{array}$ & $\begin{array}{c}\text { Excess TGA } \\
\text { plasma } \\
\end{array}$ \\
\hline & \multicolumn{6}{|c|}{ Clotting time } \\
\hline $\min$ & \multicolumn{2}{|c|}{$\mathrm{sec}$} & \multicolumn{2}{|c|}{$\mathrm{sec}$} & \multicolumn{2}{|c|}{$\mathrm{sec}$} \\
\hline $\begin{array}{r}1 \\
3 \\
5 \\
7 \\
9 \\
10 \\
11 \\
12 \\
13\end{array}$ & $\begin{array}{l}73 \\
69 \\
42 \\
32 \\
19.5 \\
16 \\
14.5 \\
15\end{array}$ & $\begin{array}{l}83 \\
50 \\
45 \\
26 \\
13 \\
12 \\
11.5 \\
12\end{array}$ & $\begin{array}{l}63 \\
59 \\
49 \\
37 \\
21 \\
17 \\
16 \\
16 \\
17\end{array}$ & $\begin{array}{l}63 \\
62 \\
47 \\
31 \\
16 \\
14 \\
12.5 \\
12.5 \\
13\end{array}$ & $\begin{array}{l}70 \\
71 \\
50 \\
35 \\
21 \\
17 \\
15.5 \\
15.5 \\
16.5\end{array}$ & $\begin{array}{l}77 \\
69 \\
52 \\
36 \\
22 \\
19 \\
16 \\
16 \\
17\end{array}$ \\
\hline
\end{tabular}

* Normal plasma and excess TGA plasma were treated with $\mathrm{BaSO}_{4}, \mathrm{Ca}_{3}\left(\mathrm{PO}_{4}\right)_{2}$ or $\mathrm{Al}(\mathrm{OH})_{3}$ and tested in the retarded TGT. Accelerated generation of thromboplastin was not evident after adsorption with $\mathrm{Al}(\mathrm{OH})_{3}$.

$\dagger$ Adsorbed for 5 minutes. 
TABLE IX

Effect of prolonged $\mathrm{Al}(\mathrm{OH})_{3}$ adsorption on $T G A$ content of normal plasma*

\begin{tabular}{|c|c|c|c|c|}
\hline \multirow{3}{*}{$\begin{array}{l}\text { Incuba- } \\
\text { tion } \\
\text { time }\end{array}$} & \multirow{2}{*}{$\begin{array}{l}\mathrm{BaSO}_{4-} \\
\text { treated } \\
\text { plasma }\end{array}$} & \multicolumn{3}{|c|}{$\mathrm{Al}(\mathrm{OH})_{\text {z-treated plasma }}$} \\
\hline & & $15 \mathrm{~min}$ & $30 \mathrm{~min}$ & $45 \mathrm{~min}$ \\
\hline & \multicolumn{4}{|c|}{ Clotting time } \\
\hline $\min$ & \multicolumn{2}{|c|}{$\mathrm{sec}$} & \multicolumn{2}{|c|}{$\mathrm{sec}$} \\
\hline 1 & 80 & 66 & 68 & 78 \\
\hline 3 & 64 & 65 & & \\
\hline 5 & 54 & 50 & 61 & 60 \\
\hline 7 & 30 & 31 & & \\
\hline 8 & 19 & 26 & 46 & 54 \\
\hline 9 & 12 & 18 & 33 & 46 \\
\hline 10 & 10 & & & \\
\hline 11 & 9.5 & 15.5 & 21 & 29 \\
\hline 12 & & & 19 & 21 \\
\hline 13 & 10 & 15 & 16 & 18 \\
\hline 15 & 11 & 14.5 & 15.5 & 17 \\
\hline 17 & & 16 & 16 & 18 \\
\hline
\end{tabular}

* Samples of fresh normal plasma were adsorbed with $\mathrm{BaSO}_{4}$ (control) and with $\mathrm{Al}(\mathrm{OH})_{3}$ for 15,30 and 45 minutes. Activity of each treated sample was measured in the TGT using normal serum diluted 1:10 in buffered saline. All samples were diluted 1:25 with buffered saline containing adsorbed normal serum as source of optimal PTA and Hageman factor. Generation of thromboplastin diminished as exposure to $\mathrm{Al}(\mathrm{OH})_{3}$ increased.

the other hand, treatment with aluminum hydroxide for 5 minutes sharply reduced the excessive TGA activity.

In order to determine the effect of prolonged aluminum hydroxide adsorption on normal plasma, samples of plasma were exposed to aluminum hydroxide for periods of 15,30 and 45 minutes and were then tested in the TGT (Table IX). Thromboplastin-generating activity diminished steadily the longer the plasma remained in contact with the aluminum hydroxide. In order to rule out the possibility that the aluminum hydroxide was adsorbing PTA or Hageman factor, barium sulfate-adsorbed normal serum was added to the TGT. Since PTA and Hageman factors are present in such serum, the diminished thromboplastin generation cannot be attributed to them.

Theoretically, the results of adsorption with aluminum hydroxide could be attributed to removal of factor V, AHG or TGA from the plasma. To determine the effect of prolonged aluminum hydroxide adsorption on factor $\mathrm{V}$ activity, 1 vol of normal plasma, treated for 15,30 and 45 minutes, was added to 9 vol of aged plasma, and onestage prothrombin times were determined on the mixtures; the prothrombin time of the aged plasma alone was 65 seconds. All of the samples shortened the prothrombin time to 36 to 38 seconds. Since fresh, unadsorbed normal plasma shortened the prothrombin time of the aged plasma to the same range, namely 37.5 seconds, it was concluded that factor $\mathrm{V}$ activity was not affected by prolonged adsorption with aluminum hydroxide.

The effect of aluminum hydroxide on AHG activity of normal plasma was evaluated by measuring the effect of such treated plasma on the prolonged clotting time of AHG-deficient plasma. Samples of the treated plasma were added to the hemophilic plasma in a $1: 9$ proportion. It was found (Table $\mathrm{X}$ ) that AHG activity was not re-

TABLE $X$

Effect of prolonged $\mathrm{Al}(\mathrm{OH})_{3}$ adsorption on $\mathrm{AHG}$ activity of normal plasma *

\begin{tabular}{|c|c|c|c|}
\hline Sample & $\underset{\text { time }}{\text { Plasma clotting }}$ & $\begin{array}{c}\text { Added AHG, } \% \\
\text { of normal }\end{array}$ & $\begin{array}{l}\text { Estimated AHG, } \\
\text { action, } \% \\
\text { of normal }\end{array}$ \\
\hline AHG-deficient plasma & $\begin{array}{l}s e c \\
480\end{array}$ & 0 & \\
\hline \multicolumn{4}{|l|}{ AHG-deficient plasma plus: } \\
\hline Normal plasma untreated & 135 & 100 & \\
\hline $\begin{array}{l}\text { Normal plasma treated for: } \\
10 \mathrm{~min} \\
30 \mathrm{~min} \\
45 \mathrm{~min}\end{array}$ & $\begin{array}{l}140 \\
142 \\
137\end{array}$ & & $\begin{array}{l}90 \\
85 \\
95\end{array}$ \\
\hline $\begin{array}{l}\text { Normal plasma untreated and } \\
\text { diluted } 1: 4 \text { in saline }\end{array}$ & 170 & 25 & \\
\hline $\begin{array}{l}\text { Normal plasma treated for } 45 \\
\text { min and diluted } 1: 4 \text { in saline }\end{array}$ & 170 & & 25 \\
\hline
\end{tabular}

* Fresh normal plasma before and after adsorption with $\mathrm{Al}(\mathrm{OH})_{3}$ for 10,30 and 45 minutes was mixed with AHGdeficient plasma and effect on clotting time noted. Plasmas were mixed in proportion of 9 parts AHG-deficient plasma to 1 part test plasma. There was no obvious effect of $\mathrm{Al}(\mathrm{OH})_{3}$ on $\mathrm{AHG}$ of normal plasma. 
TABLE XI

Influence of $\mathrm{Al}(\mathrm{OH})_{3}$ on normal plasma and excess TGA plasma in correction of defect of hemophilic plasma*

\begin{tabular}{|c|c|c|c|c|c|c|c|c|c|c|}
\hline \multirow{3}{*}{$\begin{array}{c}\text { Fraction of } \\
\text { normal or } \\
\text { excess TGA } \\
\text { plasma in } \\
\text { mixtures }\end{array}$} & \multicolumn{5}{|c|}{$\mathrm{BaSO}_{4 \text {-adsorbed }}$} & \multicolumn{5}{|c|}{$\mathrm{Al}(\mathrm{OH})_{3}$-adsorbed $\dagger$} \\
\hline & \multicolumn{2}{|c|}{ Normal plasma } & \multicolumn{2}{|c|}{ Excess TGA plasma } & \multirow[b]{2}{*}{$\begin{array}{l}\text { Rel. } \\
\text { act. }\end{array}$} & \multicolumn{2}{|c|}{ Normal plasma } & \multicolumn{2}{|c|}{ Excess TGA plasma } & \multirow[b]{2}{*}{$\begin{array}{l}\text { Rel. } \\
\text { act. }\end{array}$} \\
\hline & $\underset{\text { time }}{\text { Clotting }}$ & $\begin{array}{c}\text { Activity } \\
\text { based on } \\
\text { dilution }\end{array}$ & $\underset{\text { time }}{\text { Clotting }}$ & Activitył & & $\begin{array}{l}\text { Clotting } \\
\text { time }\end{array}$ & Activity & $\begin{array}{c}\text { Clotting } \\
\text { time }\end{array}$ & Activity $\ddagger$ & \\
\hline & $\sec$ & $\%$ & sec & $\%$ & \multirow{7}{*}{$\begin{array}{l}3.6 \\
3.6 \\
4.8 \\
3.3\end{array}$} & $\sec$ & $\%$ & \multirow[t]{2}{*}{$\sec$} & $\%$ & \\
\hline $1 / 10$ & 123 & 100 & 104 & & & & & & & \\
\hline $1 / 20$ & 139 & 50 & 110 & & & 143 & 45 & 123 & 100 & 2.2 \\
\hline $1 / 40$ & 155 & 25 & 127 & 90 & & 151 & 30 & 142 & 45 & $\begin{array}{l}2.2 \\
1.5\end{array}$ \\
\hline $1 / 80$ & 165 & 12.5 & 144 & 45 & & 162 & 14 & 156 & 25 & 1.8 \\
\hline $1 / 160$ & 184 & 6.3 & 150 & 30 & & & & & - & \\
\hline $1 / 320$ & 210 & 3.1 & 170 & 10 & & & & & & \\
\hline
\end{tabular}

* $\mathrm{BaSO}_{4}$ and $\mathrm{Al}(\mathrm{OH})_{3}$-adsorbed samples of normal and excess TGA plasma were added in various proportions to AHG-deficient plasma and clotting times were determined on mixtures. Clotting time of AHG-deficient plasma alone was 390 seconds. Relative activity (Rel. act.) was calculated from: excess TGA \% activity/normal \% activity. AHG activity of normal plasma was the same whether adsorbed in $\mathrm{BaSO}_{4}$ or $\mathrm{Al}(\mathrm{OH})_{3}$. Apparent AHG activity was 3.8 times normal when excess TGA plasma was adsorbed with $\mathrm{BaSO}_{4}$; half this increased activity disappeared after $\mathrm{Al}(\mathrm{OH})_{3}$ adsorption, suggesting TGA rather than AHG effect (see text).

+ Plasma adsorbed for 10 minutes.

$\ddagger$ Compared with $\mathrm{BaSO}_{4}$-adsorbed normal plasma.

duced by 10,30 or 45 minutes of exposure of normal plasma to aluminum hydroxide.

Since aluminum hydroxide had no apparent effect on the AHG activity of normal plasma, but did on the TGA activity of excess TGA plasma, the effect of this adsorbent on the AHG activity of excess TGA plasma was studied, barium sulfate adsorption being used as a control. Samples of adsorbed normal and excess TGA plasma were added in decreasing concentrations to hemophilic plasma ; plasma clotting times were determined on the mixtures. These results are shown in Table XI. After barium sulfate adsorption the excess TGA plasma exerted about four times the activity of normal plasma in correcting the prolonged clotting time of the AHG-deficient plasma. After adsorption for 10 minutes with aluminum hydroxide, the activity was reduced to about twice normal. Treatment with aluminum hydroxide did not apparently alter the corrective ability of the normal plasma, however. It was assumed from this and the previous experiment (Table $\mathrm{X}$ ) that the increased activity of the excess TGA plasma in correcting the clotting time of the hemophilic plasma was attributable to the accelerator effect of TGA and not to increased AHG, since AHG is apparently not adsorbed by aluminum hydroxide. The similarity of action of TGA and AHG suggests that the positions of both factors in the scheme of blood coagulation are closely allied.
Prothrombin time of diluted plasma. Thus far, the evidence places TGA activity early in the clotting reaction (prothromboplastic step), because of acceleration in the TGT associated with normal prothrombin times. In order to assess any possible second-stage activity of TGA, prothrombin times, which are independent of the first stage, were determined on diluted specimens of a number of excess TGA plasmas (Table XII). The results tend to exclude any second-stage activity comparable to that exhibited by factors $\mathrm{V}$, VII and $X$. The indirect implication is that excess TGA activity is not the result of excess factor $\mathrm{V}$.

TABLE XII

Prothrombin time of undiluted and diluted normal plasma and four samples of excess TGA plasma*

\begin{tabular}{|c|c|c|c|c|c|}
\hline \multirow[b]{3}{*}{ Plasma dilution } & \multicolumn{5}{|c|}{ Prothrombin time } \\
\hline & \multirow{2}{*}{$\begin{array}{l}\text { Normal } \\
\text { plasma }\end{array}$} & \multicolumn{4}{|c|}{ Excess TGA plasma samples } \\
\hline & & No. 1 & No. 2 & No. 3 & No. 4 \\
\hline & $\sec$ & $\sec$ & $\mathrm{sec}$ & $\sec$ & $\mathrm{sec}$ \\
\hline $\begin{array}{l}\text { Undiluted } \\
1: 5 \\
1: 10\end{array}$ & $\begin{array}{l}17-19 \\
30-49 \\
56-67\end{array}$ & $\begin{array}{l}19 \\
37.5 \\
58\end{array}$ & $\begin{array}{l}17 \\
37 \\
49\end{array}$ & $\begin{array}{l}18.8 \\
35 \\
57\end{array}$ & $\begin{array}{l}18 \\
41 \\
61\end{array}$ \\
\hline $\begin{array}{l}\text { Acceleration } \\
\text { of thrombo- } \\
\text { plastin for- } \\
\text { mation in TGT } \\
\text { times normal }\end{array}$ & Normal & 3 & 3 & 3 & 2 \\
\hline
\end{tabular}

* There was no obvious effect of excessive TGA on second step of clotting (thromboplastin activation or cothromboplastic step). 
TABLE XIII

Estimation of factor $V$ activity in excess TGA plasma*

\begin{tabular}{|c|c|c|c|c|c|}
\hline \multirow{3}{*}{$\begin{array}{l}\text { Proportion of } \\
\text { normal plasma } \\
\text { of "excess TGA } \\
\text { plasma" to } \\
\text { aged plasma }\end{array}$} & \multicolumn{5}{|c|}{ Prothrombin time } \\
\hline & \multirow{2}{*}{$\begin{array}{l}\text { Normal } \\
\text { plasma } \\
\text { values, } \\
\text { range }\end{array}$} & \multicolumn{4}{|c|}{$\begin{array}{l}\text { Excess TGA plasma } \\
\text { samples }\end{array}$} \\
\hline & & \multicolumn{4}{|c|}{ No. 1 No. 2 No. 3 No. 4} \\
\hline & $\sec$ & & & & $e c$ \\
\hline $\begin{array}{l}1: 10 \\
1: 20\end{array}$ & $\begin{array}{l}38-46 \\
48-56\end{array}$ & $\begin{array}{l}40 \\
49\end{array}$ & $\begin{array}{l}30 \\
43\end{array}$ & $\begin{array}{l}40 \\
48\end{array}$ & $\begin{array}{l}43 \\
50\end{array}$ \\
\hline \multicolumn{2}{|c|}{$\begin{array}{l}\text { Plasma acceleration } \\
\text { in TGT, times } \\
\text { normal }\end{array}$} & 4 & 3 & 2 & 2 \\
\hline
\end{tabular}

* Factor $\mathrm{V}$ activity in 4 samples of excess TGA plasma was determined by adding this plasma to aged normal plasma in proportions of 1:10 and 1:20 and determining one-stage prothrombin time on mixtures. Prothrombin time of aged plasma was 85 seconds. Only plasma no. 2 exhibiced any suggestion of excessive factor $\mathrm{V}$ activity.

Determination of factor $V$ activity in excess TGA plasma. Factor $\mathrm{V}$ activity in excess TGA plasma was assessed directly by noting the degree of correction of the prolonged prothrombin time of aged plasma on mixing the two plasmas. Three of the four studied showed no evidence of increased activity of factor $\mathrm{V}$; in the fourth instance, there was modest acceleration as compared to control values (Table XIII).

Because of this one apparent exception to an otherwise sharp differentiation of TGA and factor $\mathrm{V}$, further discrimination was sought by way of the TGT (Table XIV). Excess TGA plasma, which had approximately three times the normal thromboplastic activity in the TGT when measured in the conventional manner, was heated for 2 minutes at $56^{\circ} \mathrm{C}$ to inactivate factor $\mathrm{V}$ completely. When tested in the TGT this plasma still exhibited approximately the same degree of excess activity as before heating. (A constant source of factor $\mathrm{V}$ was added in the form of fresh AHGdeficient plasma.) Since increased thromboplastic activity persisted in the excess TGA plasma despite complete inactivation of its factor $\mathrm{V}$ content, it was assumed that factor $\mathrm{V}$ was not responsible for the increased activity of the unheated plasma in the TGT.

Effect of coumarin drug therapy. Many of the patients with thrombotic arterial and venous disease whose plasma showed the phenomenon of acceleration in the TGT were treated with one or another coumarin drug. In spite of lengthened prothrombin time and retardation of the serum activity in the TGT, their plasmas showed no reduction in excessive TGA activity. Results of the TGT of the plasma from one such patient on longterm anticoagulant therapy are illustrated in Figure 2. This patient's prothrombin time was effectively prolonged by drug therapy, but the TGA activity of his plasma remained persistently elevated. We have also observed excess TGA in the plasma of certain patients with thrombotic disease in the presence of long-standing hepatic disease with demonstrable deficiencies of factors V, VII, $\mathrm{X}$ and prothrombin.

\section{DISCUSSION}

By retarding the conventionai thromboplastin generation test (retarded TGT), we have been able to demonstrate an unusually rapid formation of plasmatic thromboplastin in 75 per cent of 52 persons with acute peripheral arterial thrombosis complicating arteriosclerosis obliterans (18) and in 50 per cent of 40 patients with idiopathic thrombophlebitis. The present study provides a detailed comparison of this accelerated clotting activity with each of the recognized blood clotting

TABLE XIV

Effect of heating excess TGA plasma for 2 minutes at $56^{\circ} \mathrm{C}$ on accelerated thromboplastin generation in TGT ${ }^{*}$

\begin{tabular}{ccc}
\hline \hline $\begin{array}{c}\text { Incubation } \\
\text { time }\end{array}$ & $\begin{array}{c}\text { Control } \\
\text { system } \dagger\end{array}$ & $\begin{array}{c}\text { Excess TGA } \\
\text { system } \uparrow\end{array}$ \\
\hline $\min$ & & \\
1 & 54 & 54 \\
3 & 56 & 53 \\
5 & 36 & 32 \\
7 & 23 & 20 \\
8 & 18.5 & 15 \\
9 & 18 & 12 \\
10 & 17 & 12 \\
11 & 16 & 11 \\
12 & 16 & 10.5 \\
14 & 17 & 11.5
\end{tabular}

* Factor $\mathrm{V}$ activity was removed from $\mathrm{BaSO}_{4}$-adsorbed excessTGA plasma by heating at $56^{\circ} \mathrm{C}$ for 2 minutes. Mixture of equal parts of this plasma and fresh unheated $\mathrm{BaSO}_{4}$-adsorbed AHG-deficient plasma (each diluted $1: 25)$ constituted plasmatic reagent for TGT. Final concentration of factor $\mathrm{V}$ was 1:50 (all from AHG-deficient plasma), and of AHG 1:50 (all from heated plasma). Normal plasma was similarly treated. TGA activity was not appreciably reduced by heating despite complete destruction of factor $\mathrm{V}$.

$\dagger$ Normal plasma heated to $56^{\circ} \mathrm{C}$ for 2 minutes $(1: 25)$ plus fresh AHG-deficient plasma (1:25).

$\ddagger$ Excess TGA plasma (exhibiting approximately 3 times normal activity in thromboplastin formation when tested in TGT prior to heating) heated to $56^{\circ} \mathrm{C}$ for 2 minutes (1:25) plus fresh AHG-deficient plasma (1:25). 
factors. This has led us to the conclusion that the rapid generation of thromboplastin in these patients cannot be satisfactorily explained on the basis of any currently identified blood-clotting factor. For clarification, we have applied to the newly recognized hypercoagulable activity the name "thromboplastin generation accelerator" (TGA), since its function is thereby described.

TGA was found to migrate electrophoretically with the $\beta$-globulins of plasma, and in this regard is like factor VII (14) and factor IX (19). TGA, like AHG (factor VIII), labile factor (V), Hageman factor, PTA, and fibrinogen, was not adsorbed from plasma by barium sulfate. TGA did not survive clotting, and is therefore absent from serum, like antihemophilic globulin (factor VIII), labile factor (V), prothrombin and fibrinogen. On the basis of these simple experiments alone, there can be only a few well authenticated coagulation factors that might have the TGA activity.

Factor $V$. TGA is considerably more heat stable than factor $\mathrm{V}$. Within 1 minute at $56^{\circ} \mathrm{C}$, factor $\mathrm{V}$ activity in human plasma was completely dissipated, while TGA remained active for at least 15 minutes. When paper electrophoresis of fresh plasma was carried out, factor $\mathrm{V}$ activity could be demonstrated in the $\beta-\gamma$ interspace (14), while TGA activity was confined to the $\beta$ fraction. Prolonged contact with aluminum hydroxide decreased TGA activity in direct proportion to the length of exposure. In contrast, factor $\mathrm{V}$ activity remained unaffected even after 45 minutes of adsorption. When assays of factor $\mathrm{V}$ were carried out on plasmas containing excessive amounts of TGA, a moderate increase was found in only one of the four studied.

Antihemophilic globulin ( $A H G$, factor VIII). TGA was found to be somewhat more stable at $56^{\circ} \mathrm{C}$ than AHG, which was completely inactivated within 10 minutes. The stability of AHG, therefore, lies midway between that of factor $\mathrm{V}$ and that of TGA.

After electrophoresis of fresh barium sulfateadsorbed plasma, maximal AHG activity could be demonstrated in the $\gamma_{1}$-globulin fraction, but not in the $\beta$-globulin zone of either normal plasma or plasma containing excess TGA. After precipitation with ammonium sulfate, AHG activity was confined to the 25 per cent saturation fraction

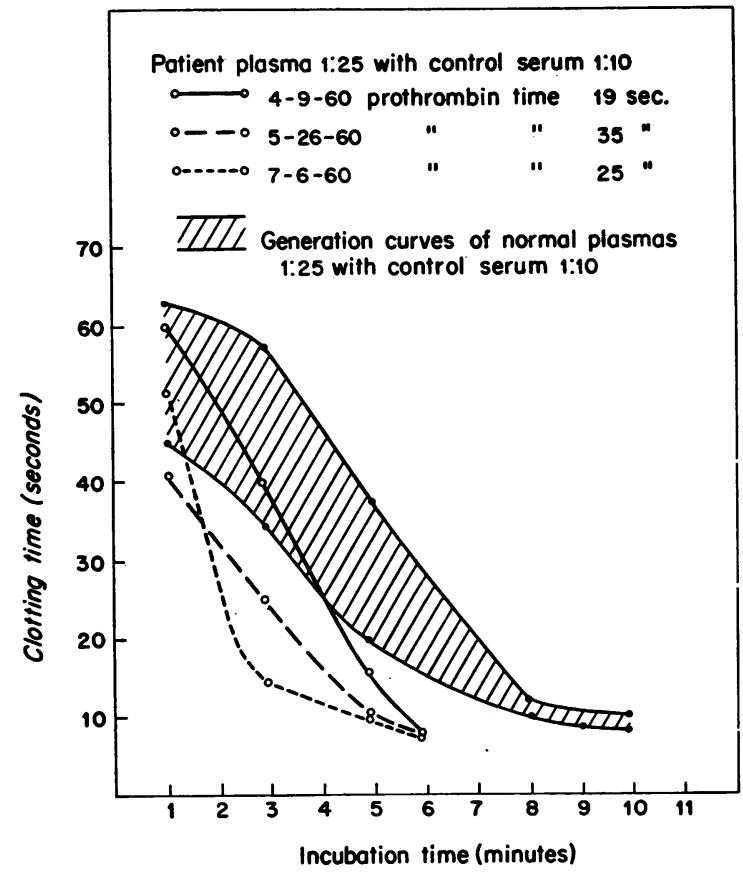

Fig. 2. EfFect of coumarin anticoagulant therapy on TGA Activity. This 54 year old man had noted intermittent claudication in right calf for 5 years. On March 8, 1960, he sustained a sudden aortoiliac occlusion. An aortofemoral bypass graft (Teflon) inserted on April 1, 1960, resulted in return of normal arterial pulsations to both lower extremities. Anticoagulant therapy with Warfarin sodium was instituted on April 26, 1960 , with plans to continue it on long-term basis. TGA activity remained essentially unchanged during a 3 month period, despite continuous and adequate therapy with Warfarin sodium.

(euglobulin) while TGA was present in the 35 to 40 per cent fraction (pseudoglobulin). Another distinction was the inability of aluminum hydroxide to adsorb AHG; after prolonged exposure, most or all of the TGA was adsorbed.

Fibrinogen. Fibrinogen is closely associated with AHG in the $\gamma_{1}$ electrophoretic and 25 per cent ammonium sulfate saturation fractions; like AHG it was cleanly separated from the zone occupied by TGA.

PTA and Hageman factor. Since both PTA and Hageman factor were present in barium sulfate-adsorbed plasma, the question might arise concerning the part played by these substances in the hypercoagulable state. The fact that both PTA and Hageman factor are present in an active state in serum $(16,17)$ would seem to distinguish them from TGA, since the thromboplas- 
tin-generating activity of serum from none of our patients with thromboembolism has been hyperactive. Furthermore, eluates of electrophoretically processed normal, barium sulfate-adsorbed serum, containing only PTA and Hageman factor as far as is known, did not enhance thromboplastin formation in a TGT of normal plasma and serum.

Both PTA, in the $\beta-\gamma$ interspace, and Hageman factor, in the $\gamma_{1}$ zone, were effectively separated from TGA, in the $\beta$ zone, by electrophoresis $(16,17)$.

Does TGA activity correspond to previously described blood coagulation factors? Increase in concentrations of factor VII (20), factor V (21), and AHG (22) in certain clinical states has been reported but does not seem pertinent in this discussion because of the significant differences between these clotting factors and TGA.

Wessler, Reimer and Deykin $(4,23)$ have described a serum activity capable of inducing thrombosis. They have entitled it serum thrombotic accelerator (STA). Since STA is present in serum and is readily adsorbed by barium sulfate, it cannot be reconciled with the properties of TGA.

The absence of TGA in serum, its resistance to barium sulfate adsorption, and its greater heat stability separate it from the prephase accelerator described by Fisch (24).

Waaler (25) has reported that there is an "activation product" resulting from the interaction of PTA and Hageman factor. Certain properties of activation product and TGA are similar: electrophoretic mobility, property of being unaffected by coumarin drugs, and susceptibility to ammonium sulfate precipitation. However, Waaler found activation product reduced four-fifths by heating plasma for 30 minutes at $37^{\circ} \mathrm{C}$, whereas TGA is unaltered by this same treatment. Furthermore, Waaler states that "activation product was unstable when in plasma" and "in serum a great amount of activation product was found." Neither of these descriptions is compatible with our observations of TGA activity. We are unable to find in the literature any description of a coagulation activity like that of TGA.

Function of TGA. TGA appeared to influence primarily the rate of formation, and possibly the yield, of plasma thromboplastin. In the TGT, peak thromboplastic activity was reached in one- half to two-thirds the time required by normal plasma. In addition, the activity of the thromboplastin produced was usually greater than that of the control, as evidenced by shorter clotting times in the substrate plasma. When TGA was partially removed from excess TGA plasma by adsorption with aluminum hydroxide, both the rate of formation and the amount of thromboplastin formed were reduced.

If TGA's function lies in the generation of thromboplastin, it might act in the initial prothromboplastic step, in the second or activation step, or both. These two steps can be distinguished by the prothrombin time test of Quick ( 7$)$, since the addition of an extract of brain to plasma apparently results in complete bypass of the prothromboplastic step with all the factors involved. Prothrombin times were determined in the usual manner, as well as with five- and tenfold dilutions of plasma in order to detect any minute shortening of the prothrombin times. In both undiluted and diluted plasmas, prothrombin times of excess TGA plasmas were uniformly within normal limits. This would seem to isolate TGA's position in the scheme of clotting to the initial step, in association with platelets, Hageman factor, AHG, PTC and PTA.

Routine detection of excess plasmatic TGA. The original description of the TGT by Biggs and Douglas included adsorption of the plasmatic reagent with aluminum hydroxide (10); since this reagent adsorbs TGA, it is possible that those who use this technic may be unable to detect all of the TGA activity. Furthermore, the BiggsDouglas test is carried out with the adsorbed plasma diluted only fivefold, so that the normal endpoint is reached in 2 or 3 minutes. In the Duckert modification (11) of the TGT, plasma is adsorbed with barium sulfate and is then diluted 25-fold. TGA is not adsorbed and excessive amounts may be detected because slight acceleration over the normal reaction rate may be perceptible. In our experience, an even greater dilution of the plasma $(1: 50)$ is needed to recognize accelerated thromboplastin generation unequivocally.

To date, our studies have been carried out largely in patients with arteriosclerosis obliterans or idiopathic thrombophlebitis. Because of the nature of our selection of patients, excess TGA 
TABLE XV

Distinguishing properties of TGA

\begin{tabular}{|c|c|c|c|c|c|c|c|}
\hline \multirow[b]{2}{*}{ Coagulation factor } & \multicolumn{4}{|c|}{ Present in:* } & \multirow[b]{2}{*}{$\begin{array}{l}\text { Lability } \\
\text { at } 56^{\circ} \mathrm{C}, \\
\text { gradet }\end{array}$} & \multirow[b]{2}{*}{$\begin{array}{l}\text { Electrophoretic } \\
\text { localization }\end{array}$} & \multirow[b]{2}{*}{$\begin{array}{l}\text { Effect of } \\
\text { coumarin } \\
\text { drug } \\
\text { therapy }\end{array}$} \\
\hline & Plasma & $\begin{array}{c}\mathrm{BaSO}_{4-} \\
\text { adsorbed } \\
\text { plasma }\end{array}$ & $\begin{array}{c}\mathrm{Al}(\mathrm{OH})_{3-} \\
\text { adsorbed } \\
\text { plasma }\end{array}$ & Serum & & & \\
\hline TGA & + & + & 0 & 0 & 2 & $\beta$ & 0 \\
\hline AHG & + & + & + & 0 & 3 & $\gamma_{1}$ & 0 \\
\hline Factor V & + & + & + & 0 & 4 & $\beta-\gamma(14)$ & 0 \\
\hline PTC (IX) & + & 0 & 0 & + & 1 & $\beta(19)$ & + \\
\hline Factor VII & + & 0 & 0 & + & $\hat{1}$ & $\beta(14)$ & + \\
\hline Factor X & + & 0 & 0 & + & $3(27)$ & $\alpha(26)$ & + \\
\hline Prothrombin & + & 0 & 0 & 0 & & $\alpha_{2}(14)$ & + \\
\hline PTA & + & + & + & + & $1(28)$ & $\beta-\gamma(17)$ & 0 \\
\hline Hageman factor & + & + & + & + & $1(28)$ & $\gamma_{1}(16)$ & 0 \\
\hline Fibrinogen & + & + & + & 0 & & $\begin{array}{l}\text { Point of } \\
\text { appl. (14) }\end{array}$ & 0 \\
\hline Platelets & + & 0 & 0 & 0 & & Point of appl. & 0 \\
\hline
\end{tabular}

* Key: $+=$ present $; 0=$ absent.

+ Graded on a basis of 0 to 4,0 representing nonlability, and 4 greatest lability.

$\ddagger$ Key: $+=$ depressed; $0=$ no depression.

activity was usually found to be associated with recent thrombosis. Before it is concluded that the excess TGA activity is simply the result of the thrombosis, it may be recalled that normal plasma exhibits a modest coagulative activity in the $\beta$-globulin zone indistinguishable from TGA. Furthermore, in one patient studied serially for 3 years and in whom there was no further clinical evidence of thrombosis, excess TGA activity persisted unaltered. It should be stated that in one patient the excess TGA activity disappeared within 3 weeks.

Additional evidence that TGA is not prothrombin, or factor VII, IX or X, all of which tend to be depressed by coumarin-type therapy, is the fact that excess TGA activity is unaltered by such therapy. Since thrombi tend to disappear during anticoagulant therapy, the persistence of excess TGA activity again raises the question of any direct relationship between excessive TGA and thrombosis. The distinguishing properties of TGA are summarized in Table XV.

Deficiency of TGA. As with all of the other known coagulation factors, it is to be expected that deficiency states of TGA will be discovered. Unfortunately, it is not possible to distinguish a deficiency of TGA from a deficiency of AHG by any currently available TGT. Deficiency of either TGA or AHG is to be suspected when the generation of thromboplastin from the patient's plasma is limited, but is normal from the patient's serum. Deficiency of AHG could be distinguished from that of TGA by adding aluminum hydroxide-adsorbed normal plasma to the TGT, since this would contain AHG but not TGA; if such a mixture should lead to a normal generation of thromboplastin, deficiency of AHG would be confirmed. Since such a distinction has not been made in the past, it is possible that certain patients believed to have "classic hemophilia" may indeed suffer from deficiency of TGA. Perhaps with a differentiating test available, a re-evaluation of women with apparent AHG deficiency, as in vascular hemophilia or thrombasthenic hemophilia (12), should be carried out.

\section{SUM MARY}

We have described a new component of the coagulation mechanism. This substance, which we have named thromboplastin generation accelerator. or TGA, appears to be responsible for the accelerated formation of plasma thromboplastin observed in certain patients with intravascular thrombosis. It is a moderately heat-labile protein associated with the $\beta$-globulins. It is present in fresh plasma but not in serum. Its site of action seems to be the initial stage of clotting, where it appears to influence primarily the rate of formation, and possibly the yield, of plasma thromboplastin. It is unaffected by therapy with coumarin drugs.

\section{REFERENCES}

1. Mustard, J. F. Blood coagulation in subjects with and without clinical evidence of atherosclerotic vessel disease. Canad. med. Ass. J. 1958, 79, 554. 
2. Sharnoff, J. G. Increased pulmonary megakaryocytes -probable role in postoperative thromboembolism. J. Amer. med. Ass. 1959, 169, 688.

3. McDonald, L., and Edgill, M. Changes in coagulability of the blood during various phases of ischaemic heart-disease. Lancet 1959, 1, 1115.

4. Wessler, S., and Reimer, S. M. The role of human coagulation factors in serum-induced thrombosis. J. clin. Invest. 1960, 39, 262.

5. Owen, C. A., Jr., and Thompson, J. H., Jr. Thrombosis from the viewpoint of a blood coagulationist in Pathogenesis and Treatment of Cerebrovascular Disease, W. S. Fields, Ed. Springfield, Ill., Charles C Thomas, 1961, pp. 105-125.

6. Spittel, J. A., Jr., Pascuzzi, C. A., Thompson, J. H., Jr., and Owen, C. A., Jr. Acceleration of early stages of coagulation in certain patients with occlusive arterial or venous diseases: Use of a modified thromboplastin generation test to evaluate clot acceleration. Proc. Mayo Clin. 1960, 35, 37.

7. Quick, A. J. On the quantitative estimation of prothrombin. Amer. J. clin. Path. 1945, 15, 560.

8. Hurn, M., Barker, N. W., and Magath, T. B. The determination of prothrombin time following the administration of Dicumarol, 3,3'-methylenebis (4-hydroxycoumarin), with special reference to thromboplastin. J. Lab. clin. Med. 1945, 30, 432.

9. Owen, C. A., Jr., Mann, F. D., Hurn, M. M., and Stickney, J. M. Evaluation of disorders of blood coagulation in the clinical laboratory. Amer. J. clin. Path. 1955, 25, 1417.

10. Biggs, R., and Douglas, A. S. The thromboplastin generation test. J. clin. Path. 1953, 6, 23.

11. Duckert, F., Flückiger, P., Isenschmid, H., Matter, M., Vogel-Meng, J., and Koller, F. A modification of the thromboplastin generation test: Role of calcium, factor V and factor VII in prothrombin conversion initiated by active blood thromboplastin. Acta haemat. (Basel) 1954, 12, 197.

12. Owen, C. A., Jr., and Thompson, J. H., Jr. Soybean phosphatides in prothrombin-consumption and thromboplastin-generation tests: Their use in recognizing "thrombasthenic hemophilia." Amer. J. clin. Path. 1960, 33, 197.

13. Mertz, E. T., and Owen, C. A. Imidazole buffer: Its use in blood clotting studies. Proc. Soc. exp. Biol. (N. Y.) 1940, 43, 204.

14. Owen, C. A., Jr., and McKenzie, B. F. Application of paper electrophoresis to separation of bloodclotting factors. J. appl. Physiol. 1954, 6, 696.

15. Lewis, J. H., Walters, D., Didisheim, P., and Mer- chant, W. R. Application of continuous flow electrophoresis to the study of the blood coagulation proteins and the fibrinolytic enzyme system. 1. Normal human materials. J. clin. Invest. 1958, 37, 1323.

16. Thompson, J. H., Jr., Spittel, J. A., Jr., Pascuzzi, C. A., and Owen, C. A., Jr. Laboratory and genetic observations in another family with the Hageman trait. Proc. Mayo Clin. 1960, 35, 421.

17. Rosenthal, R. L. Properties of plasma thromboplastin antecedent (PTA) in relation to blood coagulation. J. Lab. clin. Med. 1955, 45, 123.

18. Spittel, J. A., Jr., Pascuzzi, C. A., Thompson, J. H., Jr., and Owen, C. A., Jr. Accelerated thromboplastin generation in patients with acute peripheral arterial occlusion complicating arteriosclerosis obliterans. Unpublished data.

19. Aggeler, P. M., Spaet, T. H., and Emery, B. E. Purification of plasma thromboplastin factor B (plasma thromboplastin component) and its identification as a beta ${ }_{2}$ globulin. Science 1954, 119, 806.

20. Loeliger, A., and Koller, F. Behaviour of factor VII and prothrombin in late pregnancy and in the newborn. Acta haemat. (Basel) 1952, 7, 157.

21. Forwell, G. D., and Ingram, G. I. C. The effect of adrenaline infusion on human blood coagulation. J. Physiol. (Lond.) 1957, 135, 371.

22. Pitney, W. R., and Elliott, M. H. Plasma antihaemophilic-factor concentrations in the Australian aborigine and in conditions associated with hyperglobulinaemia. Nature (Lond.) 1960, 185, 397.

23. Reimer, S. M., Wessler, S., and Deykin, D. Serum thrombotic accelerator (STA) activity: Its relation to the first phase of clotting. Proc. Soc. exp. Biol. (N. Y.) 1960, 105, 438.

24. Fisch, U. Über einen neuen Accelerator der Blutthrombokinasebildung. Thromb. Diath. haemor. 1958, 2, 60.

25. Waaler, B. A. Contact activation in the intrinsic blood clotting system. Scand. J. clin. Lab. Invest. 1959, 11, suppl. 37.

26. Duckert, F. On the properties of the StuartPrower factor in New Blood Clotting Factors, I. S. Wright, F. Koller and F. Streuli, Eds. Stuttgart, Friedrich-Karl Schattauer-Verlag, 1959, pp. 32-36.

27. Graham, J. B. Stuart clotting defect and Stuart factor. Ibid., pp. 22-31.

28. Soulier, J. P. Our present knowledge on PTA factor. Ibid., pp. 123-131. 